\title{
COMPARISON OF SUBJECTIVE ESTHETIC PERCEPTIONS OF DENTISTS
WITH DIFFERENT GENDER AND CLINICAL EXPERIENCES WITH
OBJECTIVE DENTOLABIAL ESTHETIC MEASUREMENTS
}

\section{ABSTRACT}

Objective: This study aimed to evaluate the consistency of specific measurable dentolabial criteria between the esthetic values accepted in the literature and the subjective opinions of physicians.

Materials and Methods: Four associate professors and four research assistants in the field of prosthodontics were selected as the examiners in the study. Photographs of smiles (focusing on the mouth region of the face) taken from 200 volunteers were examined. The results of the objective measurements of the curvature of the incisal edge and lower lip parallelism, the incisal edge and lower lip contact, the laugh line, the buccal corridor and the interincisal line and midline variables, and the subjective assessments of the evaluators were compared using Cochran's Q test.

Results: Esthetic perception is subjective; however, there was a significant correlation between the objective measurements and subjective perceptions in the incisal edge and lower lip parallelism, laugh line, and buccal corridor variables. No statistically significant difference was found between the objective computer measurements and the evaluations of the male and female examiners or between the perceptions of the specialists (associate professors) and the research assistants.

Conclusion: There is no consensus between esthetically objective findings and subjective perceptions.

Keywords: Dentolabial analysis, esthetic, subjective perceptions, prosthodontic treatment.
Şükriye Ece Geduk ${ }^{1}$

*Onur Şahin ${ }^{2}$

Neslin Velioğlu ${ }^{3}$

ORCID IDs of the authors:

Ş.E.G. $0000-0003-2569-8428$

O.Ş. 0000-0002-8018-6946

N.V. $\quad 0000-0003-0210-3348$

How to Cite: Geduk ŞE, Şahin O, Velioğlu N. Comparison of Subjective Esthetic Perceptions of Dentists with Different Gender and Clinical Experiences with Objective Dentolabial Esthetic Measurements. Cumhuriyet Dent J 2020;23:3:209-220.

*Corresponding Author:

Department of Prosthodontics, Faculty of Dentistry, Alanya Alaaddin Keykubat University Alanya/Antalya, Turkey.

Phone: +902425106140 Fax: +902425106144 E-mail: sonurs60@hotmail.com 


\section{INTRODUCTION}

Since a smile is one of the most important means of nonverbal communication, it has an important place in an individual's social identity and selfperception. ${ }^{1}$ A beautiful smile enables an individual to be warmly accepted in social interactions. The increasing importance of esthetics and social communication has placed greater emphasis on the prominence of smile esthetics in dental treatments. ${ }^{2-5}$

Esthetics is not absolute; it is highly subjective. ${ }^{6}$ Although the perception of beauty is a subjective experience, there are some universal rules that transcend this subjectivity and provide objective criteria about what is pleasing to the human eye. These basic esthetic standards can enable clinicians to achieve satisfactory, quantitative, scientific and predictable designs. ${ }^{7}$ The physician must understand the basic components of the smile to regulate and optimize the esthetics by understanding the complex relationships between the teeth, gum structure, and lips. ${ }^{8-9}$

Many studies in the literature have evaluated dental esthetics from different perspectives. ${ }^{5,8,10}$ Mauro Fredeani ${ }^{10}$ stated that, to achieve successful esthetic results, it is essential to plan esthetic dental and gingival treatments after the facial, dentolabial, and phonetic parameters are identified.

In the present study, the compliance of some measurable dentolabial criteria, which are subjectively evaluated by physicians who are experts in the field of prosthodontics working on smile design, is compared with objective measurements. Thus, it aimed to be a guide in terms of identifying the recommended factors for esthetic treatment planning.

\section{MATERIALS AND METHODS}

This three-stage study includes eight examiners who subjectively evaluated the smiles in the photographs of 200 volunteers as being either "esthetic" or "non-esthetic" based on five different dentolabial criteria: incisal edge parallelism, incisal edge and lower lip contact, laugh line, buccal corridor, interincisal line, and midline. The same photographs were also evaluated using objective measurements within the limits stated in the literature, and the objective results were compared with the subjective findings.

\section{a) Study Sample}

The study was carried out using the photographs of 200 volunteer participants from Zonguldak Bülent Ecevit University Faculty of Dentistry, Zonguladk, Turkey. The participants were informed about the scope of the study, and they signed a consent form. Approval for the study was obtained from the Zonguldak Bülent Ecevit University Clinical Research Ethics Committee with the conclusion 2018/24 (dated 19/12/2018 and Protocol No. 2018-246-19/12).

To eliminate the effect of color differences on esthetic perception, the following criteria were applied. Participants who had previously received orthodontic treatment or who had any restoration, coloration, or tooth deficiency at the anterior teeth, active periodontal disease, poor oral hygiene, or trauma to the jaw-face area, were excluded from the study so as not to affect the results.

\section{b) Procedure for Taking the Photographs}

To standardize the photographs, the participants were positioned with their hands hanging to the side and their feet slightly open while the head was fixed with ear bars (cephalostat) and the occlusal plane was parallel to the ground with the forehead supported (Figure 1).

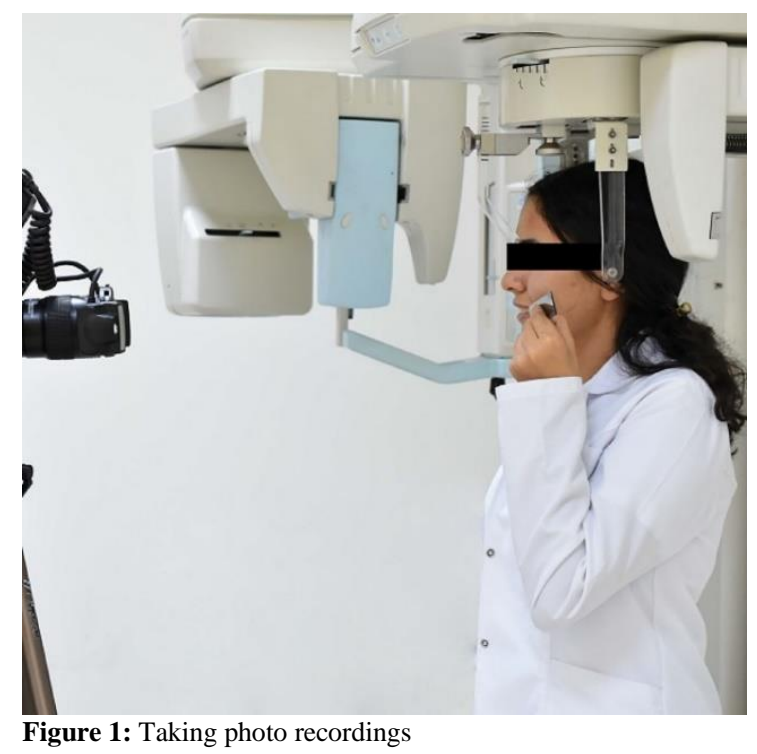


To ensure this parallelism, the participant was situated so that the Frankfurt horizontal plane was parallel to the ground using external reference points (porion and orbitale points). ${ }^{11}$ Care was taken to ensure that the faces of the individuals did not contain any elements that could be distracting and affect the esthetic evaluation, such as herpes, excessive beards, piercing accessories, and intensive make-up.

Photographs were taken using a digital camera (Canon EOS 7D Mark II), macro lens (Canon EF 100mm f / 2.8L Macro IS USM), twin flash (Canon Macro Twin Lite MT-24EX), and a tripod (WT3770). The Canon $100 \mathrm{~mm}$ 1:1 magnification prime lens, which was used to produce all the images, was preferred to minimize the distances and magnifications due to distance. All the photographs were taken by the same person, under the same indoor artificial fluorescent lighting with a shutter speed of 1/125, an aperture of F32, and an ISO 200 setting in manual mode. The tripod and the camera were not moved until the photo shoot was finished. Using Adobe Photoshop CC 2017 (San Jose, CA, USA), the photographs were cropped to show the teeth, lips, tip of the nose, and mentolabial sulcus. The photographs were numbered from 1 to 200 and saved in Joint Photographic Experts Group (JPEG) format. c) Selecting the Examiners and Evaluating the Photographs

Four associate professors and four research assistants from Zonguldak Bulent Ecevit University Faculty of Dentistry Department of Prosthodontics were selected as the examiners. All the photographs were delivered to the examiners using separate external memory drives and separate forms, each containing five pages. Thus, any time constraint related to the evaluation and the possibility of being influenced by each other were prevented. While examining the photographs, the examiners were informed that they should disregard the shape, arrangement, size of the teeth, and the form of the lips.

\section{d) Determining the Criteria and Analyzing the} Photographs

In this study, the most common variables, such as incisal edge and lower lip parallelism, incisal edge and lower lip contact, laugh line, buccal corridor, interincisal line, and midline, which are objectively measurable according to concrete parameters, were examined. The examination criteria and the evaluation intervals are presented the Table 1. All measurements were performed using Adobe Photoshop CC 2017. 
Table 1. Summary of the criteria and range used for this study

\begin{tabular}{|c|c|c|c|}
\hline Criterias in this study & Definition & $\begin{array}{l}\text { Classification criteria in computer } \\
\text { measurement }\end{array}$ & $\begin{array}{l}\text { Measurements on Adobe } \\
\text { Photoshop CC } 2017\end{array}$ \\
\hline $\begin{array}{l}\text { Incisal } \\
\text { paralellism }\end{array}$ & $\begin{array}{l}\text { The incisal edge or smile line } \\
\text { is defined as an imaginary line } \\
\text { passing through the cutting } \\
\text { edges of the four upper-front } \\
\text { teeth and the tip of the canine } \\
\text { teeth. }\end{array}$ & $\begin{array}{l}\text { The parallel relationship was classified } \\
\text { as "esthetic" and the straight or reverse } \\
\text { curvature relationship was classified as } \\
\text { not esthetic }\end{array}$ & \\
\hline $\begin{array}{l}\text { Incisal edge and lower } \\
\text { lip paralellism }\end{array}$ & $\begin{array}{l}\text { It is the contact relationship of } \\
\text { the incisal edge with the upper } \\
\text { limit of the lower lip. }\end{array}$ & $\begin{array}{l}\text { The light contact relationship was } \\
\text { classified as "esthetic" and non-contact } \\
\text { or covering position classified as "not } \\
\text { esthetic". }\end{array}$ & \\
\hline Laugh line & $\begin{array}{l}\text { Lip line or laugh line; is the } \\
\text { amount of teeth that appear in } \\
\text { the vertical direction during } \\
\text { the smile. }\end{array}$ & $\begin{array}{l}\text { The middle laugh line was classified as } \\
\text { "esthetic" and the low or high laugh } \\
\text { line was classified as "not esthetic". }\end{array}$ & \\
\hline Buccal corridor & $\begin{array}{l}\text { Labial or buccal corridor (also } \\
\text { called negative space); is the } \\
\text { gap formed between the buccal } \\
\text { surfaces of the posterior teeth } \\
\text { and the corners of the mouth } \\
\text { during smile. }\end{array}$ & $\begin{array}{l}\text { Buccal corridor widths between } 2-15 \% \\
\text { were classified as "esthetic" and } \\
\text { widths outside this range were } \\
\text { classified as "not esthetic" } \\
\text { Proportional measurement of the } \\
\text { buccal corridor: (A-B)/A*100 }\end{array}$ & \\
\hline
\end{tabular}

\section{e) Statistical Analysis}

In this study, the data obtained from eight examiners and the computer measurements were transferred to the IBM SPSS V23 software program. In the data set, descriptive statistics on the data obtained as a result of the examiners' evaluations and the computer measurement were combined with all the values related to the five dentolabial variable categories. Cochran's Q Test was performed to determine the concordance between the specialists (the associate professors)
(S1, S2, S3, S4) and the research assistant (A1, A2, A3, A4) examiners, between the male and female examiners, and between all the examiner subcategories and computer measurements. The analysis results are presented as frequency (percentage). Significance level was taken as $\mathrm{p}$ $<0.05$.

\section{RESULTS}

The results of the compliance between all the examiners and the computer measurements for incisal edge parallelism are shown in Table 2. 
Table 2. Compliance results for incisal edge parallelism

\begin{tabular}{cccccc}
\hline Examiners & Not esthetic* & Esthetic* & Multiple comparison & Cochran Q & p \\
\hline S1 & 42 & 58 & de & & \\
S2 & 46.5 & 53.5 & cd & & \\
S3 & 39 & 61 & ade & & \\
S4 & 37.5 & 62.5 & d & 175.005 & $<0.001$ \\
A1 & 23.5 & 76.5 & b & & \\
A2 & 67.5 & 32.5 & c & \\
A3 & 20.5 & 79.5 & c & \\
A4 & 51.5 & 48.5 & ae & \\
Computer & 43.5 & 56.5 & ad & & \\
\hline
\end{tabular}

*n(\%), a-e: there is no difference between examiners with the same character in each measurement.

According to Cochran's Q Test, there was a statistically significant correlation between S1, $\mathrm{S} 2, \mathrm{~S} 3, \mathrm{~S} 4, \mathrm{~A} 4$, and the computer measurement ( $\mathrm{p}$ $<0.001)$. Moreover, there was a statistically significant correlation between all the specialists and the computer measurements $(\mathrm{p}=0.164)$ (Table $3)$.

Table 3. Compliance results for incisal edge parallelism between specialists and computer

\begin{tabular}{cccccc}
\hline Examiners & Not esthetic* & Esthetic* & Multiple comparison & Cochran Q & $\mathrm{p}$ \\
\hline S1 & 42.5 & 57.5 & $\mathrm{a}$ & & \\
S2 & 46.5 & 53.5 & $\mathrm{a}$ & & \\
S3 & 39 & 61 & $\mathrm{a}$ & 6.514 & 0.164 \\
S4 & 37.5 & 62.5 & $\mathrm{a}$ & & \\
Computer & 43.5 & 56.5 & $\mathrm{a}$ & & \\
\hline
\end{tabular}

*n(\%), a-e: there is no difference between examiners with the same character in each measurement.

The results of the compliance between all the examiners and the computer measurements for the relationship between the incisal edge and the lower lip variables are shown in Table 4.
According to Cochran's Q Test, there was a statistically significant correlation between $\mathrm{S} 1$, $\mathrm{S} 2$, and the computer measurements $(\mathrm{p}<0.001)$.

Table 4. Compliance results for relationship between the incisal edge and lower lip

\begin{tabular}{cccccc}
\hline Examiner & Not esthetic* & Esthetic* & Multiple comparison & Cochran Q & $\mathrm{p}$ \\
\hline S1 & 58.5 & 41.5 & ae & & \\
S2 & 71 & 29 & ad & & \\
S3 & 42.5 & 57.5 & bc & & \\
S4 & 50 & 50 & ce & 195.868 & $<0.001$ \\
A1 & 46 & 54 & bce & & \\
A2 & 82 & 18 & d & \\
A3 & 53 & 47 & ce & \\
A4 & 36 & 64 & b & \\
Computer & 65.5 & 34.5 & a & & \\
\hline
\end{tabular}

*n(\%), a-e: there is no difference between examiners with the same character in each measurement.

The results of the compliance between all the examiners and the computer measurements for laugh line are shown in Table 5. According to
Cochran's Q Test, there was a statistically significant correlation between S2, S3, A1, A3, $\mathrm{A} 4$, and the computer measurements $(\mathrm{p}<0.001)$. 
Table 5. Compliance results for the laugh line

\begin{tabular}{cccccc}
\hline Examiner & Not esthetic* & Esthetic* & Multiple comparison & Cochran Q & $\mathrm{p}$ \\
\hline S1 & 70 & 30 & $\mathrm{e}$ & & \\
S2 & 57.5 & 42.5 & abde & & \\
S3 & 49.5 & 50.5 & $\mathrm{~d}$ & & \\
S4 & 24.5 & 75.5 & $\mathrm{c}$ & 166.548 & $<0.001$ \\
A1 & 51.5 & 48.5 & ac & \\
A2 & 69.5 & 30.5 & be & \\
A3 & 54.5 & 45.5 & ad & \\
A4 & 51 & 49 & abd & \\
Computer & 52 & 48 & ad & \\
*n(\%). a-e: there is no difference between examiners with the same character in each measurement.
\end{tabular}

*n(\%). a-e: there is no difference between examiners with the same character in each measurement.

The results of the compliance between all the examiners and the computer measurements for the buccal corridor are shown in Table 6. According to Cochran's Q Test, there was a statistically significant correlation between S2, S3, A1, A3, $\mathrm{A} 4$, and the computer measurements $(\mathrm{p}<0.001)$.

Table 6. Compliance results for buccal corridor

\begin{tabular}{cccccc}
\hline Examiner & Not esthetic* & Esthetic* & Multiple comparison & Cochran Q & $\mathrm{p}$ \\
\hline S1 & 74.5 & 25.5 & $\mathrm{be}$ & & \\
S2 & 59.5 & 40.5 & $\mathrm{de}$ & & \\
S3 & 59 & 41 & $\mathrm{~d}$ & & \\
S4 & 17 & 83 & $\mathrm{c}$ & 253.736 & $<0.001$ \\
A1 & 39.5 & 60.5 & $\mathrm{a}$ & & \\
A2 & 77 & 23 & $\mathrm{~b}$ & \\
A3 & 51.5 & 48.5 & $\mathrm{ad}$ & \\
A4 & 38 & 62 & $\mathrm{a}$ & \\
Computer & 52 & 48 & $\mathrm{ad}$ & & \\
\hline
\end{tabular}

*n(\%). a-e: there is no difference between examiners with the same character in each measurement.

The results of compliance between all the examiners and the computer measurements for the interincisal line and the midline are shown in Table 7. According to Cochran's Q Test, there was no statistically significant correlation between the examiners and the computer measurements for those two variables $(\mathrm{p}<0.001)$.

Table 7. Interincisal line and midline alignment results

\begin{tabular}{cccccc}
\hline Examiner & Not esthetic* & Esthetic* & Multiple comparison & Cochran Q & $\mathrm{p}$ \\
\hline S1 & 85 & 15 & $\mathrm{c}$ & & \\
S2 & 28 & 72 & $\mathrm{de}$ & & \\
S3 & 28.5 & 71.5 & $\mathrm{de}$ & & \\
S4 & 15.5 & 84.5 & $\mathrm{e}$ & 556.475 & $<0.001$ \\
A1 & 22 & 78 & $\mathrm{de}$ & & \\
A2 & 79 & 21 & $\mathrm{c}$ & \\
A3 & 45.5 & 54.5 & $\mathrm{~b}$ & \\
A4 & 35.5 & 64.5 & $\mathrm{bd}$ & \\
Computer & 6 & 94 & $\mathrm{a}$ & & \\
\hline
\end{tabular}

*n(\%), a-e: there is no difference between examiners with the same character in each measurement. 
The compliance levels between the computer measurements and the examiners are shown in Figure 2.

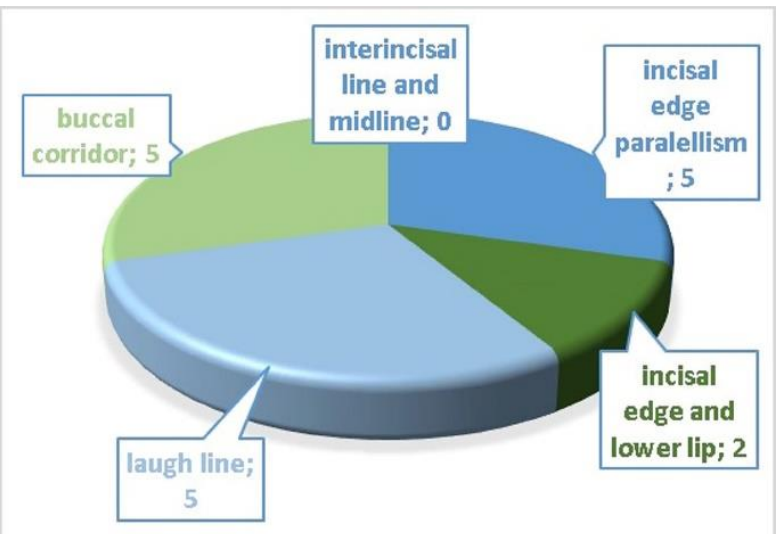

Figure 2: Schematic representation of computer measurements and rating of agreement between observers

When the findings were evaluated, in general, it was observed that there was no statistically significant agreement between the mean of all the examiners (subjective perception) and the computer measurements (objective measurements) when each dentolabial variable was compared ( $\mathrm{p}<0.001)$.

In terms of evaluating the incisal edge and lower lip contact relationship, laugh line, buccal corridor, interincisal line and midline, no statistical correlation was found between the four experienced specialists (associate professors) and the four research assistants (specialty students) and the computer measurements $(\mathrm{p}<0.001)$. It was determined that the esthetic perception was compatible between the specialists and the computer measurements based on the incisal edge parallelism criteria $(\mathrm{p}=0.164)$.

There was no statistically significant correlation between the four male and four female examiners and the computer measurements for all the esthetic criteria variables $(\mathrm{p}<0.001)$.

When the entire data set was evaluated, although the difference between the specialists and research assistants and between the men and women was not statistically significant, the numerical results showed that the subjective evaluations of the specialists were comparable to the research assistants by $10 / 7$ and the women to men by $11 / 6$ were more consistent with the objective computer measurements (Figure 3).

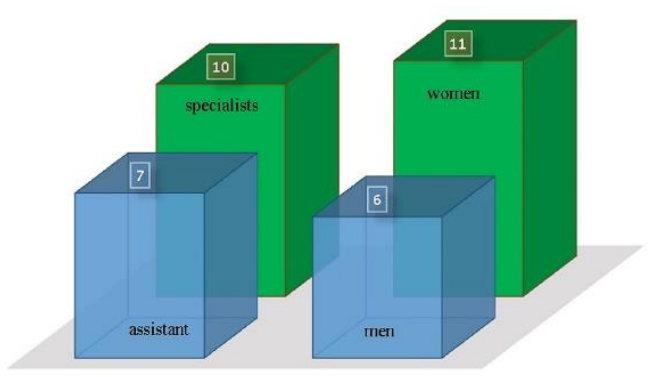

Figure 3: Schematic representation of compliance levels of specialist / assistant and female / male observers with computer measurements respectively

\section{DISCUSSION}

In previous studies, dental evaluation measurements were made on extracted teeth, ${ }^{12,13}$ while in recent studies, plaster models, computer-based images, or intraoral evaluations have been conducted. ${ }^{12,14-17}$ Hasanreisoglu et al. ${ }^{14}$ photographed the faces of 100 dental students in full smile, obtained a plaster model from their upper jaws, and measured the anterior tooth dimensions, the presence of golden ratio, and the relationship between the facial ratios of the anterior teeth on both the models and the computer-based images. In the present study, due to the high number of samples, it was thought that taking photographs of smiles would be the most practical method, so the photographs taken from 200 students were transferred to a computer and the measurements were made in Adobe Photoshop CC 2017.

Nomura et al..$^{18}$, Krishnan et al..$^{19}$, and Chang et al. ${ }^{20}$ received photographic records of posed smiles on the grounds that they were reproducible. Based on the same reasoning, in the present study, the participants were photographed with a posed smile. To avoid the factors that could affect the esthetic perception, such as hair, fashion, and eyes, and to focus on the lower $1 / 3$ of the face, the photographs of the participants were cropped from the tip of the nose to the chin.

Esthetic perception is a subjective concept; it varies from person to person and it can be affected by situations, such as age, gender, occupational group, social status, and cultural preferences. 
Accordingly, there may be a difference of opinion between dentists and individuals (laypersons) who have not received dental education. ${ }^{21-24}$ Basaran et $a l .{ }^{25}$ included painters as well as specialists and laypersons in their study evaluating the effect of buccal corridors on esthetic perception because painters and specialists received esthetic training in their professions. Many studies ${ }^{26-28}$ have shown that the oral esthetic assessments of specialists or dentists are more critical and sensitive than those of individuals who have not received dental training. Consequently, in the present study, an evaluator group consisting of four associate professors and four research assistants, who are experts in the prosthodontic department, were chosen because their awareness and discrimination were believed to be higher than general dentists. Individuals who did not receive dental training were not selected to be examiners in the study because the inclusion criteria consisted of dental terms and it was necessary to have a dental education to make an accurate assessment.

Basting et al. ${ }^{29}$ compared specialists and general dentists' esthetic perceptions on smile and face photographs; they reported that the evaluations made by general dentists were more positive than the ones made by the specialists in both photography groups. Kokich et al. ${ }^{30}$ examined asymmetric and symmetrical changes on the teeth; they obtained evaluations from both specialists and general dentists because they are more critical than laypersons. According to the results of the present study the scores of the specialist examiners were more compatible with the objective measurements than the scores of the research assistant examiners.

Wolfart et al. ${ }^{31}$ examined the relationship between subjective judgments and objective measurements on upper anterior teeth; they reported that there was no significant difference between the subjective perceptions of men and women. Chang et al. ${ }^{20}$ evaluated the variability of facial attractiveness and smile esthetics according to gender; they discovered that the raters' sex had no effect on the results. While there no statistically significant difference was found between the male and female examiners in the present study, the compliance of the subjective scores with the objective computer measurements was higher for the female examiners than the male examiners.

Different criteria have been considered in the literature to evaluate esthetic perception. The present study evaluated the most common variables (incisal edge parallelism, incisal edge and lower lip contact relationship, laugh line, buccal corridor, and interincisal line and midline) because they are objectively measurable according to concrete parameters.

Clinicians usually increase overbite so that the incisal edge follows the lower lip parallelism. Ker et $a .^{32}$ found that when the line passing through the incisal edges of the upper teeth follows the concave curvature of the lower lip, laypersons evaluated that to be esthetically ideal. In their study, Parekh et al. ${ }^{33}$ found that ideal curved smile arches were more acceptable (84$95 \%$ ) than straight smile arches, which were only 50-60\% acceptable. The change of lip contour from person to person may have an effect on the smile arc, but it is critical that the line passing through the incisal edges of the upper teeth follows the lower lip in parallel..$^{20,32,34-36}$ When the results of the present study were analyzed, it was observed that five of the examiners were in agreement with the objective measurements made on the computer, while the other three did not agree with the literature knowledge about the incisal edge parallelism. Moreover, all four of the specialist examiners agreed with the objective computer measurements in terms of their esthetic views on incisal edge parallelism. The results reinforce the idea that the imaginary line passing through the incisal edges of the upper incisors is parallel to the upper limit of the lower lip in an esthetically pleasing smile.

In an ideal smile, while the central and canine teeth are required to have light contact with the lower lip, the lateral teeth are expected to be shorter in the range of about $0.5-1.5 \mathrm{~mm}$ from the 
lower lip. ${ }^{37,38}$ It has been reported that a smile in which the upper teeth do not contact the lower lip, or in which they slightly touch the lower lip, is more esthetic than a smile in which the teeth are covered by the lower lip. ${ }^{39}$ When the results of the present study were examined, the computer measurement results were consistent with only two of the eight examiners. Almost all the examiners who did not comply with the objective computer measurements evaluated the incisal edge and the lower lip contact in the photographs as being more "esthetic" than "non-esthetic". This may be due to the fact that there is no esthetic consensus on the relationship between the incisal edge and the lower lip contact, or that this relationship affects esthetic perception less than other criteria.

Kokich et al..$^{30}$ examined the effect of the distance between the lip and the teeth on esthetic appreciation in the case of smiles; in that study, the orthodontists and laypersons both stated that gingival visibility of $3 \mathrm{~mm}$ or more had a negative effect on gingival appeal, and even the general dentists did not perceive the height of $4 \mathrm{~mm}$ to be esthetically undesirable. In another study ${ }^{40}$, orthodontic experts found $2 \mathrm{~mm}$ of gingival visibility to be esthetically negative; for dentists and laypeople $4 \mathrm{~mm}$ of gingival visibility was found to be esthetically negative. Although these two studies stated that general dentists have a higher acceptable threshold than orthodontists, the results of both indicate that gingival visibility of 1-2 $\mathrm{mm}$ can be accepted as esthetically pleasing by both groups. Since the appearance of the gingiva and the upper anterior teeth decreases with aging, it may be better for the patient to have a small amount of gum visibility in a prosthetic treatment. ${ }^{30} \mathrm{Ker}$ et al. ${ }^{32}$ considered that, while the ideal gingival visibility in a smile is $2.1 \mathrm{~mm}$, lips covering the teeth with up to a $4 \mathrm{~mm}$ laughing line is an acceptable lower limit, and the $3.6 \mathrm{~mm}$ gum line is an acceptable upper limit. When the results of the present study were evaluated, agreement was observed between the majority of the examiners and the computer measurements. Thus, it can be said that there is a general consensus about the effect of the laugh line on esthetic perception. In the planning of treatment, it is recommended that the laugh line be designed in such a way that $3 / 4$ of the upper incisors be visible and the gum line limit should be $1-2 \mathrm{~mm}$ to ensure a more esthetically pleasing result. The different responses given by some examiners may be related to the perception that a high laugh line creates a cheerful impression in individuals. ${ }^{41}$

Ritter et al. ${ }^{42}$ stated that the width of the buccal corridor is $1 \mathrm{~mm}$ larger in men than women. Thus, the buccal corridor measurement was calculated proportionally in order to avoid this difference. In the literature, there is no consensus on the effect of buccal corridor width on smile attractiveness. Hulsey ${ }^{43}$, Ritter et al. ${ }^{42}$, and Johnson et al. ${ }^{44}$ argued that the width of the buccal corridor, which they call negative space, does not affect the attractiveness of a smile. Moore et al. ${ }^{45}$ examined the effects of buccal corridors on the attractiveness of smiles; while smiles with minimal buccal corridors received the most appreciation, those with large buccal corridors were found to be esthetically insufficient. Basaran et al. ${ }^{25}$ found that a $2 \%$ wide smile type was the most esthetically pleasing and a $28 \%$ narrow smile type was the least pleasing. Ioi et $a l^{46}$ reported that while narrow buccal corridors were more popular than wide ones, the esthetic acceptability limit was $10-15 \%$ of the buccal corridor width. When the results of the present study were examined, it was seen that there was agreement between the computer measurements and the evaluations of the majority of the examiners. When evaluating the buccal corridor width in prosthetic diagnoses and treatments, a satisfactory result can be obtained when the $2-15 \%$ width range is taken as a reference. It is recommended that clinicians avoid creating a very wide or very narrow buccal corridor when finishing treatment. The reason for the differences of opinion of the examiners who did not comply with the computer measurement results may be due to the same reason reported in studies that emphasized that the buccal corridor does not affect esthetic perception. ${ }^{42-44}$

In the study by Kokich et al. ${ }^{40}$ orthodontists found that the $4 \mathrm{~mm}$ midline deviation was 
esthetically unacceptable, while general dentists and laypersons could not distinguish the midline deviation even when it was $4 \mathrm{~mm}$. Springer et al. ${ }^{36}$ examining the effect of midline deviation on smile esthetics; they found the maximum acceptable midline deviation amount to be $3.2 \mathrm{~mm}$. Ker et $a l .{ }^{32}$ evaluated the degree of esthetic appreciation created by various dentofacial parameters in laypersons; they found that the maximum tolerable deviation was $2.9 \mathrm{~mm}$, but they reported that it was noteworthy that $1 / 3$ of the participants found the $4.3 \mathrm{~mm}$ midline deviation to be acceptable. In the present study, the computer measurement results did not match the evaluations of any of the examiners. All the examiners evaluated the midline deviation more critically than the computer and their "non-esthetic" scores were higher than the objective measurements. This shows that professionally trained examiners consider the $4 \mathrm{~mm}$ midline deflection to be more critical and they might not find it to be esthetically pleasing. In contrast, in the literature, a lower tolerance threshold in the midline deviations results in more esthetically pleasing results.

While evaluating the relationship between the dentolabial variables and esthetic perception in the literature, visuals are presented to the participants with computer generated changes and the highest scores or esthetically acceptable ranges are reported. In the present study, natural, unmanipulated smile photos of the volunteers were presented to the examiners to obtain their professional views and the results were compared with the values reported in previous studies. It is thought that the present study is a literature review in terms of the dentolabial variables, and that the consistency of the results is compared with the opinions of the physicians who are professionals in their field; thus, this study makes a scientific contribution to the literature because it is one of the few studies that was performed with this method. It is hoped that the obtained results can guide physicians in terms of the external reference points to be determined during the examination and the factors to be considered about the treatment.

\section{CONCLUSIONS}

In summary, this study found that:

1. In the evaluation of smile esthetics, it was seen that the gender of the examiners did not make a significant difference in the results.

2. Although not statistically significant, when the numerical values were examined, it was seen that the women's esthetic evaluations were more consistent with the objective measurements than the men's esthetic evaluations. Similarly, specialists gave answers that were more consistent with the objective measurements than the research assistants.

3. No consensus was found between the esthetically objective findings and the subjective views. It is thought that the most accurate diagnosis and treatment results can be achieved when personal opinions are supported by the objective esthetic values accepted in the literature.

4. It is thought that more detailed and comprehensive results can be obtained if a twostage evaluation is conducted by taking photographs of smiling faces.

\section{ACKNOWLEDGEMENTS}

This study was presented as an expertise thesis at Zonguldak Bulent Ecevit University Faculty of Dentistry Department of Prosthodontics on 13.12.2019. The authors do not have any financial interest in the companies whose materials are included in this article.

\section{CONFLICTS OF INTEREST STATEMENT}

The authors have no conflict of interests.

\section{$\ddot{O} Z$}

Amaç: Bu çalı̧̧manin amacı bazı ölçülebilir dentolabial kriterlerin literatürde kabul edilen değerleri ile hekimlerin subjektif estetik görüşleri arasındaki uyumu değerlendirmektir. Gereç ve Yöntemler: Protetik Diş Tedavisi alanında dört uzman ve dört araştırma görevlisi diş hekimi çalışmada öznel değerlendirici olarak seçildi. 200 gönüllü katıllımcıdan sadece ăğz bölgesi görünecek şekilde alınan gülümseme fotoğraflart incelendi. Kesici eğimi ve alt dudak paralelliği, kesici eğimi ve alt dudak temas ilişkisi, gülme hattl, bukkal koridor ve interinsizal çizgi ve orta hat değişskenlerinin objektif ölçüm sonuçları ve değerlendiricilerin subjektif değerlendirmeleri 
Cochran $Q$ testi ile karşılaştırıld. Bulgular: Estetik algl sübjektiftir. Kesici eğimi ve alt dudak paralelliği, gülme hattı ve bukkal koridor değiş̧kenlerinde objektif ölçümler ile subjektif görüşler arasinda anlamlı bir ilişsi bulundu. Erkek ve kadin bireyler arasinda, benzer şekilde uzmanlar ve araştırma görevlileri arasinda istatistiksel olarak anlaml bir fark bulunmadl. Sonuçlar: Estetik olarak objektif bulgular ile öznel görüşler arasında fikir birliği yoktur. Anahtar

Kelimeler: Dentolabial analizler, estetik, subjektif görüsler, protetik tedavi.

\section{REFERENCES}

1. Tarantili VV, Halazonetis DJ, Spyropoulos MN. The spontaneous smile in dynamic motion. Am $\mathbf{J}$ Orthod Dentofacial Orthop 2005;128:8-15.

2. Ekrem O, Yavuz İ, Yıldız O. Gülümseme estetiğinin değerlendirilmesi. Journal of Ataturk Uni Dent 2018;28:583-591.

3. Gochman DS. The measurement and development of dentally relevant motives. J Public Health Dent 1975;35:160-164.

4. Goldstein RE. Study of need for esthetics in dentistry. J Prosthet Dent 1969;21:589-598.

5. Mandalı G, Biçer AZY, Bulut Z, Konakçı DB. Anterior bölgede estetik yaklaşımlar: olgu sunumu. Journal of Ataturk Uni Dent 2011;80-85.

6. Goldstein RE. Esthetics in pediatric dentıstry. In: Caprioglio C, Caprioglio A, Caprioglio D(eds). Esthetics in Dentistry: 2nd ed. London: Decker; 1998:537-573.

7. Levine JB, Finkel S. Esthetic Diagnosis: A ThreeStep Analysis. Smile Design Integrating Esthetics and Function: Essentials in Esthetic Dentistry. 2016;2:1-42.

8. Garber DA, Salama MA. The esthetic smile: diagnosis and treatment. Periodontol 2000 1996;11:1828.

9. Gill DS, Naini FB, Tredwin CJ. Smile esthetics. Dent Update 2007;34:152-4, 7-8.

10. Fradeani M. Facial Analysis. In: Fradeani M, Barducci G(eds). Esthetic rehabilitation in fixed prosthodontics. New Orleans: Quintessence Publishing Company; 2008:35-63.
11. Moorrees C.F.A., Kean MR. Natural head position, a basic consideration in the interpretation of cephalometric radiographs. Am. J. Phys. Anthropol June 1958, 16: 213-234.

12. Gillen RJ, Schwartz RS, Hilton TJ, Evans DB. An analysis of selected normative tooth proportions. Int $\mathbf{J}$ Prosthodont 1994;7:410-417.

13. Ash MM. Wheeler's atlas of tooth form. 5th ed. Philadelphia, Saunders: Elsevier; 1984:158-163.

14. Hasanreisoglu U, Berksun S, Aras K, Arslan I. An analysis of maxillary anterior teeth: facial and dental proportions. J Prosthet Dent 2005;94:530-538.

15. Iscan MY, Kedici PS. Sexual variation in buccolingual dimensions in Turkish dentition. Forensic Sci Int 2003;137:160-164.

16. Lavelle CL. Maxillary and mandibular tooth size in different racial groups and in different occlusal categories. Am J Orthod 1972;61:29-37.

17. Magne P, Belser U. Understanding the intact tooth and the biomimetic principle. Bonded porcelain restorations in the anterior dentition: a biomimetic approach. Geneva: Quintessence; 2002:23-57.

18. Nomura S, Freitas KMS, Silva P, Valarelli FP, Cançado RH, Freitas MR, et al. Evaluation of the attractiveness of different gingival zeniths in smile esthetics. Dental Press J Orthod 2018;23:47-57.

19. Krishnan V, Daniel ST, Lazar D, Asok A. Characterization of posed smile by using visual analog scale, smile arc, buccal corridor measures, and modified smile index. Am J Orthod Dentofacial Orthop 2008;133:515-523.

20. Chang CA et al. Smile esthetics from patients' perspectives for faces of varying attractiveness. Am J Orthod Dentofacial Orthop 2011;140:171-180.

21. Abu Alhaija ES, Al-Shamsi NO, Al-Khateeb S. Perceptions of Jordanian laypersons and dental professionals to altered smile esthetics. Eur J Orthod 2011;33:450-456.

22. Flores-Mir C, Silva E, Barriga MI, Lagravere MO, Major PW. Lay person's perception of smile esthetics in dental and facial views. J Orthod 2004;31:204-209.

23. Hall D, Taylor RW, Jacobson A, Sadowsky PL, Bartolucci A. The perception of optimal profile in 
African Americans versus white Americans as assessed by orthodontists and the lay public. Am J Orthod Dentofacial Orthop 2000;118:514-525.

24. Hwang HS, Kim WS, McNamara JA, Jr. Ethnic differences in the soft tissue profile of Korean and European-American adults with normal occlusions and well-balanced faces. Angle Orthod 2002;72:72-80.

25. Başaran G, Veli İ, Genç C, Özer T, Arslan SG. Bukkal koridorların gülümseme estetiğine etkisinin değerlendirilmesi. Turk J Orthod 2011;24:47-56.

26. Mantzikos T. Esthetic soft tissue profile preferences among the Japanese population. Am J Orthod Dentofacial Orthop 1998;114:1-7.

27. Nguyen DD, Turley PK. Changes in the Caucasian male facial profile as depicted in fashion magazines during the twentieth century. Am J Orthod Dentofacial Orthop 1998;114:208-217.

28. Cavalcanti SM, Guerra SMG, Valentim FB, Rosetti EP. Esthetic perception of smiles with different gingival conditions. Gen Dent 2019;67:66-70.

29. Basting RT, da Trindade Rde C, Florio FM. Comparative study of smile analysis by subjective and computerized methods. Oper Dent 2006;31:652-659.

30. Kokich VO, Kokich VG, Kiyak HA. Perceptions of dental professionals and laypersons to altered dental esthetics: asymmetric and symmetric situations. Am J Orthod Dentofacial Orthop 2006;130:141-151.

31. Wolfart S, Quaas AC, Freitag S, Kropp P, Gerber WD, Kern M. Subjective and objective perception of upper incisors. J Oral Rehabil 2006;33:489-495.

32. Ker AJ, Chan R, Fields HW, Beck M, Rosenstiel S. Esthetics and smile characteristics from the layperson's perspective: a computer-based survey study. J Am Dent Assoc 2008;139:1318-1327.

33. Parekh S, Fields HW, Beck FM, Rosenstiel SF. The acceptability of variations in smile arc and buccal corridor space. Orthod Craniofac Res 2007;10:15-21.

34. Tjan AH, Miller GD, The JG. Some esthetic factors in a smile. J Prosthet Dent 1984;51:24-28.
35. Sarver DM. The importance of incisor positioning in the esthetic smile: the smile arc. Am J Orthod Dentofacial Orthop 2001;120:98-111.

36. Springer NC, Chang C, Fields HW, Beck FM, Firestone AR, Rosenstiel S, et al. Smile esthetics from the layperson's perspective. Am J Orthod Dentofacial Orthop 2011;139:91-101.

37. Sharma PK, Sharma P, editors. Dental smile esthetics: the assessment and creation of the ideal smile. Seminars in orthodontics 2012;18:193-201.

38. Miller CJ. The smile line as a guide to anterior esthetics. Dent Clin North Am 1989;33:157-164.

39. Bhatia S, Kohli S, Tandon P, Agarwal A. Smile line and facial esthetics. Indian J Dent Res 2011;29 :117120.

40. Kokich VO, Jr., Kiyak HA, Shapiro PA. Comparing the perception of dentists and lay people to altered dental esthetics. J Esthet Dent 1999;11:311-324.

41. Machado AW. 10 commandments of smile esthetics. Dental Press J Orthod 2014;19:136-157.

42. Ritter DE, Gandini LG, Pinto Ados S, Locks A. Esthetic influence of negative space in the buccal corridor during smiling. Angle Orthod 2006;76:198203.

43. Hulsey CM. An esthetic evaluation of lip-teeth relationships present in the smile. Am J Orthod 1970;57:132-144.

44. Roden-Johnson D, Gallerano R, English J. The effects of buccal corridor spaces and arch form on smile esthetics. Am J Orthod Dentofacial Orthop 2005; 127:343-350.

45. Moore T, Southard KA, Casko JS, Qian F, Southard TE. Buccal corridors and smile esthetics. Am J Orthod Dentofacial Orthop 2005;127:208-213.

46. Ioi H, Kang S, Shimomura T, Kim SS, Park SB, Son WS, et al. Effects of buccal corridors on smile esthetics in Japanese and Korean orthodontists and orthodontic patients. Am J Orthod Dentofacial Orthop 2012;142:459-465. 